\title{
EFFECT OF ETHANOLIC EXTRACT OF TINOSPORA CRISPA L FROM INDONESIA IN ALLOXAN INDUCED LIVER DAMAGE
}

\author{
EM SUTRISNA, FAHRIZAL ARIA SAHADEWA, IKBAR ARDIANSYAH
}

Department of Pharmacology Faculty of Medicine of Universitas Muhammadiyah Surakarta, Indonesia

Email: em_sutrisna@yahoo.com,Em.Sutrisna@ums.ac.id

Received: 08 Feb 2017 Revised and Accepted: 19 Jun 2017

\begin{abstract}
Objective: The objective of this study was to evaluate the hepatoprotective effect of Tinospora crispa L. (Bratawali).

Methods: Twenty four male rats wistar strain were divided into four groups. The serum alanine amino transferase (ALT) and aspartate aminotransferase (AST) of rats were measured (day 0). Rats then were injected by alloxan monohydrate at doses of 120 mg/200 bw (g) intraperitoneally. Four days later, the serum ALT and AST of rats were measured (second measurement/day 4) and then were treated by extract appropriate their groups. Group 1 was treated by $2 \mathrm{ml}$ of distilled water orally; group 2,3 and 4 were treated by $70 \%$ ethanolic extract of $T$. crispa L. (EETC) at dose of 100; 200 and $400 \mathrm{mg} / 200 \mathrm{bw}(\mathrm{g}) /$ day respectively orally. After $10 \mathrm{~d}$ treatment, serum ALT and AST were measured (third measurement/day 14). At the end of this treatment, all rats were killed for histopathologic examination of their liver. The histopathologic examination was performed to assess the number of pyknotic nuclei, karyorrhexis nuclei and karyolysis nuclei.
\end{abstract}

Results: The result of this study showed that the ethanolic extract of T. crispa L at dose of 100 and $200 \mathrm{mg} / 200 \mathrm{gbw}$ can reduce blood ALT and AST significantly $(\mathrm{P}<0.05)$. From the histopathological examination, it was found that the number of pyknotic nuclei, karyorrhexis nuclei and karyolysis nuclei of EETC at doses of 100 and $200 \mathrm{mg} / 200$ body weight $(\mathrm{g}$ ) lower than negative control.

Conclusion: The present study shows that the 70\% EETC at dose of 100 and $200 \mathrm{mg} / 200$ body weight (g) has hepatoprotective effect against alloxan induced liver damage.

Keywords: Tinospora crispa L, ALT, AST, Hepatoprotective

(C) 2017 The Authors. Published by Innovare Academic Sciences Pvt Ltd. This is an open access article under the CC BY license (http://creativecommons.org/licenses/by/4.0/) DOI: http://dx.doi.org/10.22159/ijpps.2017v9i8.17592

\section{INTRODUCTION}

Indonesia is a country located at the equator with a tropical climate. This causes Indonesia to become rich in biodiversity. Indonesian people use many medicinal plants for health maintenance. One of the herbs often used by Indonesian people is Bratawali (Tinospora crispa L.) [1]. Tinospora crispa L (T. crispa) is a medicinal plant species of the genus of Tinospora Miers [2]. WHO report published in 2014 stated that in Indonesia the number of death caused by cancer is 103.100 . Approximately, $12.3 \%$ of the deaths were due to liver cancer [3]. In Indonesia, Bratawali is traditionally used to treat fever, gout and rheumatic diseases [4]. Indian people use this medicinal plant to treat syphilis, rheumatoid arthritis, impotence, hepatitis, diuretic, bronchitis and etc [5]. The previous research by Prastiwi, 2012 stated that the methanolic extract of T. crispa L. from Indonesia has hepatoprotective effect in mice balb/c induced by hepatitis B virus vaccine [6]. Research by Harwoko and Choironi, 2016 which employed by thin layer chromatography found that flavonoids and alkaloids are indicated to exist in $70 \%$ ethanolic extract of T. crispa L[7], meanwhile Ibahim at al stated that the antioxidant effect as the active compound is of T crispa $\mathrm{L}$ is phenolic and alkaloid [8]. This study to determine the hepato protective effect of $70 \%$ ethanolic extract of T. crispa L (EETC) on male rat's wistar strain induced by alloxan. Alloxan at dose of $120 \mathrm{mg} /$ body weight $(\mathrm{kg})$ can cause hepatitis. Alloxan cause damage on liver and kidney. The lack of liver function was marked by elevating in ALT and AST. The structural change of liver induced by alloxan were marked by vacuolations and necrosis of hepatocytes [9].

\section{MATERIALS AND METHODS}

\section{Plant collection and determination}

T. crispa L. was harvested from Sukoharjo, Central Java, Indonesia in November 2015. The plant was determined by the Laboratory of
Biology, University of Muhammadiyah Surakarta, Indonesia with voucher specimen number: 051/PB/2016.

\section{Preparation extract}

T. crispa L. was washed to remove all dirt and then placed in drying cabinet at a temperature of $40{ }^{\circ} \mathrm{C}$. The dried T. crispa L. was crushed into powder, sifted and weighed. The powder was macerated by $70 \%$ ethanol (1: 7). After $2 \mathrm{~d}$, the filtrate was poured and put in a container. The residue was re-macerated by $70 \%$ ethanol (1: 4). Two days later, the filtrate was poured and joined with the first filtrate. All filtrate was evaporated by a vacuum evaporator.

\section{The study protocol}

Twenty four male rats wistar strain were divided into four groups. Each group consisted 6 rats. All rats were adapted for $7 \mathrm{~d}$ by giving food and drink to ad libitum. The serum alanine amino transferase (ALT) and aspartate aminotransferase (AST) of rats were measured using colorimetric method (first measurement/day 0). Rats were injected by alloxan monohydrate (Sigma Aldrich USA, CAS: 2244-113) at doses of $100 \mathrm{mg} / 200 \mathrm{bw}$ (g) intraperitoneally.

Four days later, the serum ALT and AST of rats were measured (second measurement/day 4) and then were treated by extract appropriate their groups. Group 1 was treated by $2 \mathrm{ml}$ of distilled water orally; group 2,3 and 4 were treated by $70 \%$ ethanolic extract of T. crispa L. (EETC) at dose of 100; 200 and $400 \mathrm{mg} / 200 \mathrm{bw}$ (g)/day respectively orally. After $10 \mathrm{~d}$ treatment, serum ALT and AST were measured (third measurement/day 14). At the end of this treatment, all rats were killed by cervical dislocation. The liver were taken and stained by HE (Haematoxylin eosin) for histopathologic examination. This study protocol was approved by Health research ethics committee of Faculty of Medicine of Universitas Muhammadiyah Surakarta with no: 228/B.1/KEPK-FKUMS/IV/ 2016. 


\section{Data analyzis}

The blood ALT and AST level were expressed by mean \pm SD and then analyzed by ANOVA followed LSD test. The analysis of histopathology of liver was done by scoring. Pyknotic nuclei was scored 1, Karyorrhexis (score 2), and karyolysis (score 3). The examination was performed on three fields of view and taken on average each field of view.

\section{RESULTS}

\section{Blood ALT and AST level measurement}

During the experiment, all the rats looked healthy. This is evidenced by normal activity of all rats. The rat's blood ALT and AST level on day 0,4 and 14 measurement were expressed in table 1 and table 2 .

Table 1: The mean of rat's blood ALT on day 0, 4 and 14 measurement

\begin{tabular}{lllll}
\hline Groups & N & ALT(mg/dl) \pm SD & & \\
\cline { 3 - 5 } & & Day 0 & Day 4 & Day 14 \\
\hline Groups I (negative control treated by water 2 ml/200gbw) & 6 & $54.17 \pm 8.64$ & $62.50 \pm 7.01$ & $67.17 \pm 8.98$ \\
Groups II (treated by EETC at dose of $100 \mathrm{mg} / 200 \mathrm{gbw})$ & 6 & $53.17 \pm 13.79$ & $64.33 \pm 16.08$ & $55.50 \pm 14.84$ \\
Groups III (treated by EETC at dose of $200 \mathrm{mg} / 200 \mathrm{gbw}$ ) & 6 & $48.67 \pm 11.51$ & $64.00 \pm 17.81$ & $49.17 \pm 14.63^{*}$ \\
Groups IV Groups (treated by EETC at dose of 400 mg/200gbw) & 6 & $48.83 \pm 11.51$ & $73.17 \pm 15.88$ & $44.67 \pm 7.34^{*}$ \\
\hline
\end{tabular}

The mean of ALTs were expressed as mean \pm SD. The analysis of statistic was done using ANOVA followed by LSD test, * indicated significant differences on $p$ value $<0.05$ compared with groups I at the same time.

Table 2: The mean of rat's blood AST on day 0, 4 and 10 measurement

\begin{tabular}{|c|c|c|c|c|}
\hline \multirow[t]{2}{*}{ Groups } & \multirow[t]{2}{*}{$\mathbf{N}$} & \multicolumn{3}{|c|}{$\operatorname{AST}(\mathrm{mg} / \mathrm{dl}) \pm \mathrm{SD}$} \\
\hline & & Day 0 & Day 4 & Day 14 \\
\hline Groups I (negative control treated by water $2 \mathrm{ml} / 200 \mathrm{gbw}$ ) & 6 & $21.50 \pm 4.32$ & $27.50 \pm 6.60$ & $36.00 \pm 7.43$ \\
\hline Groups II (treated by EETC at dose of $100 \mathrm{mg} / 200 \mathrm{gbw}$ ) & 6 & $20.00 \pm 9.10$ & $30.67 \pm 14.90$ & $24.00 \pm 14.27^{*}$ \\
\hline Groups III (treated by EETC at dose of $200 \mathrm{mg} / 200 \mathrm{gbw}$ ) & 6 & $18.17 \pm 6.11$ & $28.83 \pm 10.65$ & $21.50 \pm 7.87^{*}$ \\
\hline Groups IV Groups (treated by EETC at dose of $400 \mathrm{mg} / 200 \mathrm{gbw}$ ) & 6 & $17.67 \pm 4.63$ & $31.00 \pm 12.52$ & $18.50 \pm 5.36^{*}$ \\
\hline
\end{tabular}

The mean of AST were expressed as mean \pm SD. Analysis of statistic was done using ANOVA followed by LSD test, * indicated significant differences on $\mathrm{p}$ value $<0.05$ compared with negative control at the same time

The first statistical test done is ANOVA test of ALT and AST on day 4. There was no significant differences between ALT and AST between treatment group (group II, III and IV) and negative control (group I) on day $4(\mathrm{p}>0.05)$.

The following test was ANOVA test of ALT and AST on day 14. From table 1, we found that the blood ALT level of EETC at doses of 100 and $200 \mathrm{mg} / 200 \mathrm{BW}(\mathrm{g})$ are lower than negative control significantly. From table 2, it can be seen that the blood AST level of EETC at doses of 100; 200 and $400 \mathrm{mg} / 200 \mathrm{BW}(\mathrm{g})$ respectively are lower than negative control significantly. It can be allegedly that the EETC has hepatoprotective effect.

\section{Histopathologic examination}

All rats were killed after measurement of blood ALT and AST on day 14. The livers were taken and stained by HE. The profile of histopathology examination of livers show different results among groups. There are different number of nucleus pyknosis, Karyorrhexis and karyolysis. The histopathologic profile among groups can be seen in fig. 1 .

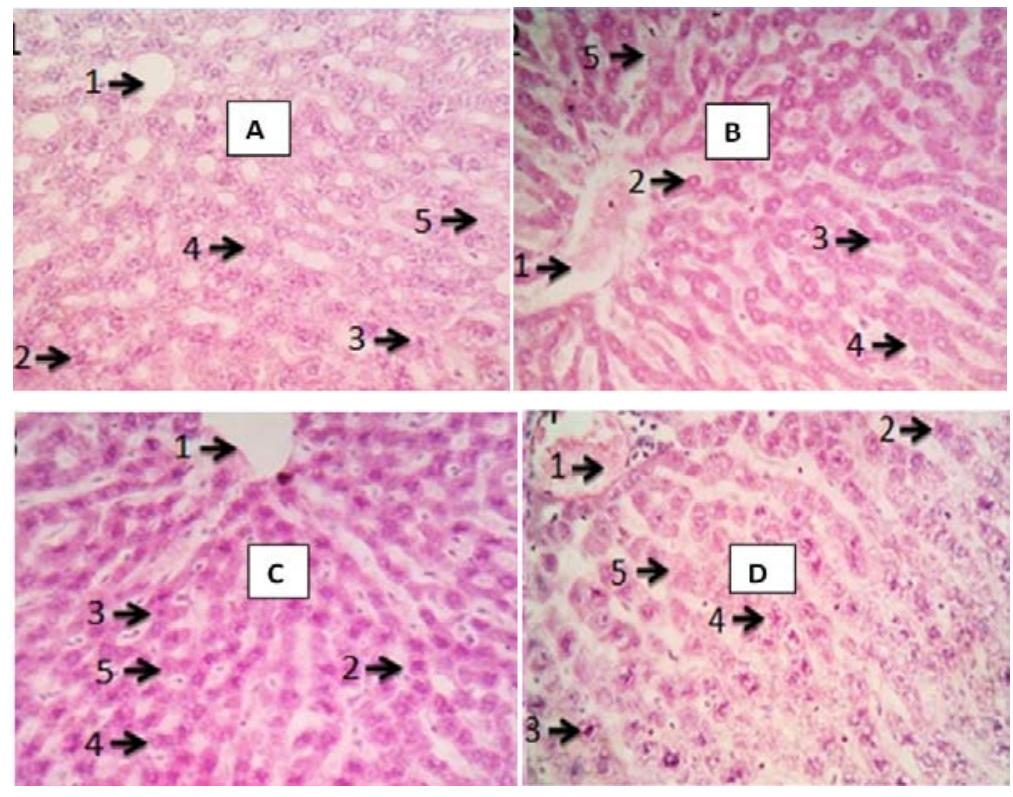

Fig. 1: Histopathology of the liver with HE staining in 4 groups; A. Group I (1. Central Vein, 2. Normal Hepatocytes, 3. Pyknotic nuclei, 4. Karyorrhexis nuclei 5. karyolysis nuclei); B. Group II (1. Central Vein, 2. Normal Hepatocytes,, 3. Pyknotic nuclei, 4. Karyorrhexis nuclei 5. Karyolysis nuclei); C. Group III (1. Central Vein, 2. Normal Hepatocytes, 3. Pyknotic nuclei, 4. Karyorrhexis nuclei 5. Karyolysis nuclei); D. Group IV (1. Central Vein, 2. Normal Hepatocytes, 3. Pyknotic nuclei, 4. Karyorrhexis nuclei, 5. Karyolysis nuclei) 
Table 3: Score of liver damage

\begin{tabular}{|c|c|c|c|c|}
\hline \multirow[t]{2}{*}{ Groups } & \multicolumn{4}{|c|}{ Score( $( \pm$ SD) } \\
\hline & Pyknosis & Karyorrhexis & Karyolysis & Total score \\
\hline Groups I (negative control treated by water $2 \mathrm{ml} / 200 \mathrm{gbw}$ ) & $50 \pm 12.5$ & $38 \pm 7.2$ & $22 \pm 8.4$ & $110 \pm 17.30$ \\
\hline Groups II (treated by EETC at dose of $100 \mathrm{mg} / 200 \mathrm{gbw}$ ) & $46 \pm 10.3$ & $32 \pm 11.4$ & $20 \pm 3.7$ & $98.8 \pm 8.28^{*}$ \\
\hline Groups III (treated by EETC at dose of $200 \mathrm{mg} / 200 \mathrm{gbw}$ ) & $41 \pm 8.3$ & $33 \pm 6.9$ & $11 \pm 4.7$ & $85.2 \pm 19.53^{*}$ \\
\hline Groups IV Groups (treated by EETC at dose of $400 \mathrm{mg} / 200 \mathrm{gbw}$ ) & $74 \pm 19.4$ & $52 \pm 12.5$ & $33 \pm 4.9$ & $159.8 \pm 20.05^{* *}$ \\
\hline
\end{tabular}

The mean of score of Liver damage were expressed as mean \pm SD. The statistical analysis was done using ANOVA followed by LSD test, * indicated significant differences on p value $<0.05$ (compared with negative control), ${ }^{* *}$ significant differences on $\mathrm{p}$ value $<0.001$ compared with negative control.

From figure-I, it can be seen that the pyknotic nuclei, karyorrhexis nuclei and karyolysis nuclei were found in all groups. From table-III, the score of liver damage of EETC at dose of 100 and $200 \mathrm{mg} / 200 \mathrm{gbw}$ were lower than negative control. It can be concluded that the EETC at dose of 100 and $200 \mathrm{mg} / 200 \mathrm{gbw}$ could regenerate the hepatocytes significantly $(\mathrm{P}<0.05)$.

\section{DISCUSSION}

This research uses alloxan to induce liver damage. This refers to the previous research done by Farokhi et al., 2011 and Lucchesi et al., 2015 [9-14]. Research by Farokhi at al., 2011 stated that injection of Alloxan monohydrate dissolved in saline intra peritoneally at dose of 120 $\mathrm{mg} /$ body weight $(\mathrm{kg}$ ) caused hepatitis that characterized by cytoplasmic vacuolations, necrosis of hepatocytes, dilated sinusoids and lymphocytic infiltrations in female rats [9]. Injection alloxan at dose of $42 \mathrm{mg} / \mathrm{bw}(\mathrm{kg})$ iv (rat's tail vein) caused change biochemical marker, structure and morphology in liver. This agent can cause degeneration of liver cells and fibrosis that associated liver disease [10].

AST and ALT were enzyme that catalyzes the transfer of amino acid aspartate and alanine respectively to group ketoglutaric acid. ALT was mainly found in the liver but AST was found in various tissues such as the heart, skeletal muscles, kidney, brain and liver $[15,16]$. ALT is present in cytosol of hepatosit, meanwhile AST was present in cytosol and mitochondria of hepatosit $[15,17]$.

Mild elevation of AST and ALT can be caused by drug toxicity $[16,18]$. In this research, the elevation of ALT and AST were induced by alloxan. Alloxan produced free radical [19]. Free radical could disrupt the DNA, protein, lipid and membrane cell resulting cell damag e [20, 21]. The EETC reduced blood level of ALT and AST. This means that the extract was thought to be able to regenerate hepatosit. The suspected mechanism of this effect was caused by antioxidant effect of T. crispa $\mathrm{L}$. The previous researches by Ibahim et al., Mohamad et al., and Zulkhairi et al., stated that T. crispa L. had antioxidant effect invitro. The methanolic extract of T. crispa L. has antioxidant activity [8]. The aqueous crude extract of T. crispa L. has antioxidant activity invitro by DPPH (1,1-diphenyl-2-picrylhydrazyl) [8,22],and TBA (Thiobarbituric acid) methods[23]. Hepatitis induced by alloxan was caused by stress oxidative. This is marked by elevation of superoxide dismutase (SOD, malondialdehyde (MDA) and gluthation (GSH) [24]. The Antioxidants can inhibit cell damage because this agent can scavenge free radical [25]. The antioxidant property of T. crispa L. is suspected by phenolic, alkaloid [8], and flavonoid content [7].

\section{CONCLUSION}

Bratawali (T. crispa L.) widely used Indonesian traditional society used to treat fever, gout and rheumatic diseases. The Previous study showed that methanol extract of T. crispa L. has a hepatoprotective effect. This outcome of this study exhibit that the $70 \%$ ethanolic extract of T. crispa L. can repair hepatosit in male rat's wistar strain. The mechanism of this effect is not clear, but several researchs alleged that the effect is mediated by antioxidant activity.

\section{ACKNOWLEDGMENT}

This study was funded by Universitas Muhammadiyah Surakarta (UMS), Indonesia. The author thanks to UMS.

\section{CONFLICT OF INTERESTS}

We declare that we have no conflict of interest regarding this publication.

\section{REFERENCES}

1. Dweck AC, Cavin JP. A review of Andawali (Tinosporacrispa). Personal Care Magazine 2006; 7:1-3.

2. Lawrence GHM. Taxonomy of vascular plants. The MacMillan Company, New York; 1951.

3. WHO, Cancer country profiles; 2014. Available from: http://www.who.int/cancer/country-profiles/en/ [Last accessed on 05 Aug 2016]

4. Harwoko, Choironi NA. Quality standardization of Brotowali (Tinospora crispa) stem extract. Trad Med J 2016;21: 6-11.

5. Dastur JF. Medicinal plants of India and Pakistan. DB.' ilala Sons and Co. Private LTD., Bombay; 1970.

6. Prastiwi R. Effect of hepatoprotector Brotowali (Tinospora cordifolia Miers) against hepatitis B virus. J Biomed 2011;4:5-10.

7. Harwoko, Choironi NA. Quality standardization of Brotowali (Tinospora crispa) stem extract. Trad Med J 2016;21: 6-11.

8. Ibahim MJ, Wan-Nor I'zzah WMZ, Narimah AHH, NurulAsyikin Z, Siti-NurShafinas SAR, Froemming GA. Anti-proliperative and antioxidant effects of Tinospora crispa (Bratawali). Biomed Res 2010;22:57-62.

9. Farokhi F, Farkha NK, Togmechi A, Band KS. Preventive effects of Prangos ferulacea (L.) Lindle on liver damage of diabetic rats induced by alloxan. Am J Physiol 2011;2:63-71.

10. Lucchesi AN, Cassettari LL, Spadella CT. Alloxan-induced diabetes causes morphological and ultrastructural changes in rat liver that resemble the natural history of chronic fatty liver disease in humans. J Diabetes Res 2015:1-11. http://dx.doi.org/10.1155/2015/494578

11. Sujith KC, Darwin R, Roosewelt C. Antidiabetic activity of methanolic extract of Butea frondosa leaves with its possible mechanism of action. Asian J Pharm Clin Res 2011;4:93-8

12. Rajaram K. Antioxidant and antidiabetic activity of Tectona grandis Linn. in alloxan induced albino rats. Asian J Pharm Clin Res 2013;6:174-7.

13. Sutrisna EM, Sujono TA, Dewi LI. Antidiabetic activity of ethanolic extract of Eugenia polyantha Wight leaf from indonesia in diabetic rat wistar strain induced by alloxan. Asian J Pharm Clin Res 2016;9:374-6.

14. Komalavalli T, Packia Lincy M, Muthukumarasamy S, Mohan VR. Antidiabetic and antihyperlipidaemic activity of Sonerila tinnevelliensis fischer whole plant in alloxan induced diabetic rats. Int J Chem Pharm Res 2015;7:53-7.

15. Rosen HR, Keefe EB. Evaluation of abnormal liver enzymes, use of liver tests and the serology of viral hepatitis: liver disease, diagnosis and management. $1^{\text {st }}$ ed. New York; Churchill livingstone publishers; 2000. p. 24-35.

16. Friedman SF, Martin P, Munoz JS. Laboratory evaluation of the patient with liver disease. Hepatology, a textbook of liver disease. Philedelphia; Saunders publication; 2003;1:661-709.

17. Sherlock S. Assessment of liver function disease of liver and biliary system: Sheila Sherlock. 10 $10^{\text {th }}$ edn. London; Blackwell science ltd; 1997. p. 17-32. 
18. Daniel SP, Marshall MK. Evaluation of the liver: laboratory tests. Schiff's diseases of the liver. 8th edn. USA; JB Lippincott publications; 1999. p. 205-39.

19. Asayama K, Nyfeler F, English D, Pilkis SJ, Burr IM. Alloxaninduced free radical production in isolated cells selective effect on islet cells. Diabetes 1984;33:1006-12.

20. Young IS, Woodside JV. Antioxidants in health and disease. J Clin Pathol 2001;54:176-86.

21. Lobo V, Patil A, Phatak A, Chandra N. Free radicals, antioxidants and functional foods: Impact on human health. Pharmacogn Rev 2010;4:118-26.

22. Mohamad HNZ, Abidin NZ. Antioxidant activity of methanol extract of Tinosporacrispaand Tabernaemontana corymbosa. Sains Malaysiana 2013;42:697-706.
23. Zulkhairi A, Abdah MA, M Kamal NH, Nursakinah I, Moklas MAM, Hasnah B, et al. Biological properties of Tinosporacrispa (Akar Patawali) and Its antiproliferative activities on selected human cancer cell lines. Mal J Nutr 2008;14:173-87.

24. Fan W, Liu A, Wang W, Zheng G, Teng A. Hepatoprotective activity of CrPic against alloxan-induced hepatotoxicity in mice. Biol Trace Elem Res 2012;149:227-33.

25. Halliwell B. How to characterize an antioxidant-an update. Biochem Soc Symp 1995;61:73-101.

\section{How to cite this article}

- $\quad$ Emsutrisna, Fahrizal Aria Sahadewa, Ikbar Ardiansyah. Effect of ethanolic extract of Tinospora crispa L from indonesia in alloxan induced liver damage. Int J Pharm Pharm Sci 2017;9(8):65-68. 